\title{
PEMBELAJARAN PENDIDIKAN JASMANI OLAHRAGA DAN KESEHATAN KELAS V SDN 11 KOTA BIMA
}

\author{
Shutan Arie Shandi \\ STKIP Taman Siswa Bima \\ arieshutan86@gmail.com
}

\begin{abstract}
Abstrak
SDN 11 Kota Bimamerupakan MI yang prestasinya lebih banyak dibandingkan MI yang lain di kawasan kecamatan Karanglewas terutama dalam bidang olahraganya. Berdasarkan observasi pendahuluan yang dilakukan pada tanggal 24 Oktober 2015 di SDN 11 Kota Bimadi peroleh informasi bahwa prestasi di bidang Pendidikan Jasmani Olahraga dan Kesehatan lebih banyak dibandingkan bidang mata pelajaran lainya, dan yang paling banyak memperoleh prestasi adalah siswa kelas V dan pada mata pelajaran Pendidikan Jasmani Olahraga dan Kesehatan nilai rata-rata siswa selalu di atas KKM (75/Amat Baik). Berangkat dari latar belakang tersebut di atas, maka penulis merumuskan permasalahan sebagai berikut: "Bagaimana Pembelajaran Pendidikan Jasmani Olahraga dan Kesehatan Kelas V di SDN 11 Kota Bima Kecamatan Mpunda". Dalam hal ini penulis menggambarkan proses pelaksanaan pembelajaran Pendidikan Jasmani Olahraga dan Kesehatan yang berada di SDN 11 Kota Bima. Jenis penelitian ini adalah penelitian lapangan (field research) dimana penulis terjun langsung pada lokasi penelitian yaitu di SDN 11 Kota Bima yang bersifat deskriptif yaitu penelitian ini hanya menjelaskan dan menggambarkan bagaimana pembelajaran Pendidikan Jasmani Olahraga dan Kesehatan Kelas V di SDN 11 Kota Bima. Metode penelitian yang digunakan adalah wawancara, dokumentasi dan observasi. Sedangkan metode analisis data menggunakan reduksi data, penyajian data dan verifikasi data. Berdasarkan hasil penelitian yang penulis lakukan, penulis berkesimpulan bahwa proses pembelajaran Pendidikan Jasmani Olahraga dan Kesehatan di SDN 11 Kota Bimadilakukan dengan tiga tahapan yaitu kegiatan awal, kegiatan inti, dan kegiatan penutup.
\end{abstract}

\section{Kata Kunci: Pembelajaran Penjas}

\section{PENDAHULUAN}

Pendidikan Jasmani Olahraga dan Kesehatan merupakan bagian integral dari pendidikan secara keseluruhan, bertujuan untuk mengembangkan aspek kebugaran jasmani, keterampilan gerak, keterampilan berpikir kritis, keterampilan sosial, penalaran, aspek pola hidup sehat dan pengenalan lingkungan bersih melalui aktivitas jasmani, olahraga dan kesehatan terpilih yang direncanakan secara sistematis dalam rangka mencapai tujuan pendidikan nasional. ${ }^{3}$ Oleh karena itu, penyelenggaraan pendidikan jasmani harus dikembangkan lebih optimal untuk membina pertumbuhan fisik dan pengembangan psikis yang lebih baik sehingga peserta didik akan lebih aktif, terampil, meSDliki pola hidup sehat dan bugar sepanjang hayat.

Pada dasarnya, pendidikan jasmani merupakan wahana untuk mendidik anak. Para ahli sepakat bahwa pendidikan jasmani merupakan alat untuk membina anak muda agar kelak mereka mampu membuat keputusan terbaik tentang aktivitas jasmani yang dilakukan dan menjalani pola hidup sehat. Aktivitas jasmani itu dapat berupa permainan atau olahraga yang terpilih.Kegiatan pembelajaran merupakan suatu aktivitas untuk mentransformasikan bahan pelajaran kepada subjek belajar pada konteks ini, guru berperan sebagai penjabar, penerjemah bahan tersebut supaya diSDliki siswa.5 Kegiatan belajar dan pembelajaran menjadi salah satu langkah dalam proses pendidikan dimana kegiatan belajar dilakukan oleh siswa sedangkan kegiatan mengajar dilaku kan oleh guru. Di dalam proses belajar dan mengajar guru harus mampu membelajarkan siswa secara optimal. Oleh karena itu, dalam pembelajaran guru harus memperhatikan komponen pembelajaran, antara lain tujuan pembelajaran, materi, metode, media dan evaluasi.

SDN 11 Kota Bima merupakan SD yang prestasinya lebih banyak dibandingkan SD yang 
lain di kawasan kecamatan Mpunda terutama dalam bidang olahraganya. Berdasarkan observasi pendahuluan melalui wawancara dengan guru Pendidikan Jasmani Olahraga dan Kesehatan kelas V bahwa prestasi di bidang Pendidikan Jasmani Olahraga dan Kesehatan lebih banyak dibandingkan bidang mata pelajaran lainya, dan yang paling banyak memperoleh prestasi adalah siswa kelas $\mathrm{V}$ dan pada mata pelajaran Pendidikan Jasmani Olahraga dan Kesehatan nilai rata-rata siswa selalu di atas KKM (75/Amat Baik). Oleh karena itu penulis hanya akan meneliti satu kelas saja yaitu kelas $\mathrm{V}$, dengan alasan bahwa kelas tersebut paling banyak memperoleh prestasi dan nilai rata-rata siswa pada mata pelajaran Pendidikan Jasmani Olahraga dan Kesehatan selalu di atas KKM (75/Amat Baik). Dari kondisi di atas maka SDN 11 Kota Bima merupakan SD yang prestasinya lebih banyak dibandingkan SD yang lain di kawasan kecamatan Mpunda terutama dalam bidang olahraganya dan kebanyakan yang memperoleh prestasi adalah kelas V. Oleh karena itu, penulis tertarik untuk melakukan penelitian dengan judul "Pembelajaran Pendidikan Jasmani Olahraga dan Kesehatan Kelas V di SDN 11 Kota Bima". Dalam hal ini penulis menggambarkan proses pembelajaran Pendidikan Jasmani Olahraga dan Kesehatan kelas V yang berada di SDN 11 Kota Bima.

\section{KAJIAN PUSTAKA}

\section{Pembelajaran Pendidikan Jasmani Olahraga dan Kesehatan}

Pendidikan jasmani adalah suatu proses pembelajaran melalui aktivitas jasmani yang di desain untuk meningkatkan kebugaran jasmani, mengembangkan keterampilan motorik, pengetahuan, dan perilaku hidup sehat dan aktif, sikap sportif, dan kecerdasan emosi. Jadi, yang penulis maksud dengan pembelajaran pendidikan jasmani olahraga dan kesehatan disini merupakan satu kesatuan mata pelajaran yang dilakukan oleh pendidik untuk membelajarkan peserta didik melalui aktivitas jasmani yang di desain untuk meningkatkan kebugaran jasmani, mengembangkan keterampilan motorik, pengetahuan, perilaku hidup sehat, dan sikap sportif.

Tujuan Pendidikan Jasmani, olahraga dan kesehatan
Apakah sebenarnya yang menjadi tujuan pendidikan jasmani, olahraga dan kesehatan? Menjawab pertanyaan demikian, banyak guru yang masih berbeda pendapat. Ada yang menjawab bahwa tujuannya adalah untuk meningkatkan keterampilan siswa dalam berolahraga. Ada pula yang berpendapat tujuannya adalah untuk meningkatkan taraf kesehatan anak yang baik, dan tidak bisa disangkal pasti ada yang mengatakan bahwa tujuan pendidikan jasmani adalah untuk meningkatkan kebugaran jasmani. Kesua jawan itu benar. Hanya saja barangkali bisa dikatakan kurang lengkap, sebab yang paling penting dari kesuanya adalah itu tujuannya bersifat menyeluruh.

\section{Ruang lingkup pendidikan jasmani, olahraga dan kesehatan}

Ruang lingkup mata pelajaran penjasorkes untuk meliputi aspek-aspek sebagai beriku:

1) Permainan dan olahraga meliputi: olahraga tradisional, permainan. Eksplorasi gerak, keterampilan lokomotor non-lokomotor,dan manipulatif, atletik, kasti, rounders, kippers, sepak bola, bola basket, bola voli, tenis meja, tenis lapangan, bulu tangkis, dan beladiri, serta aktivitas lainnya

2) Aktivitas pengembangan meliputi: mekanika sikap tubuh, komponen kebugaran jasmani, dan bentuk postur tubuh serta aktivitas lainnya

3) Aktivitas senam meliputi: ketangkasan sederhana, ketangkasan tanpa alat, ketangkasan dengan alat, dan senam lantai, serta aktivitas lainnya

4) Aktivitas ritmik meliputi: gerak bebas, senam pagi, SKJ, dan senam aerobic serta aktivitas lainnya

5) Aktivitas air meliputi: permainan di air, keselamatan air, keterampilan bergerak di air, dan renang serta aktivitas lainnya

6) Pendidikan luar kelas, meliputi: piknik/karyawisata, pengenalan lingkungan, berkemah, menjelajah, dan mendaki gunung

7) Kesehatan, meliputi penanaman budaya hidup sehat dalam kehidupan sehari-hari, khususnya yang terkait dengan perawatan tubuh agar tetap sehat, merawat lingkungan yang sehat, memilih makanan dan minuman yang sehat, mencegah dan merawat cidera, mengatur waktu istirahat yang tepat dan 
berperan aktif dalam kegiatan P3K dan UKS. Aspek kesehatan merupakan aspek tersendiri, dan secara implisit masuk ke dalam semua aspek.

\section{METODE PENELITIAN}

Metode penelitian merupakan cara ilmiah yang digunakan untuk mendapatkan data dengan tujuan dan kegunaan tertentu (Sugiyono, 2013 :2). Penelitian merupakan suatu kegiatan yang sangat penting bagi pengembangan ilmu dan bagi pemecahan suatu masalah (Satori dan Komariah, 2013: 1). Adapun metode penelitian ini menyangkut: jenis penelitian, lokasi penelitian, informan penelitian, teknik dan prosedur pengumpulan data, dan teknik analisis data. Latar penelitian ini adalah bidang pendidikan dengan mendiskripsikan tentang pembelajaran pendidikan jasmani dan olahra di SDN 11 kota Bima dalam Penelitian ini yang dipentingkan adalah proses penelitian maka data yang telah tersedia dikumpulkan kemudian dianalisa secara induktif yang hasilnya akan disajikan dalam bentuk deskriptif, atau dalam bentuk rangkaian kalimat-kalimat yang menggambarkan keadaan yang sesungguhnya yang terjadi di lapangan.

\section{HASIL DAN PEMBAHASAN}

Berdasarkan hasil analisa data mengenai pelaksanaan pembelajaran Pendidikan Jasmani Olahraga dan Kesehatan yang dilakukan di SDN 11 Kota Bima, maka dapat dibahas masalah sebagai berikut:

pembelajaran yang di buat guru mata pelajaran Pendidikan Jasmani Olahraga dan Kesehatan di SDN 11 Kota Bimasecara prosedural sebelum proses pembelajaran guru merencanakan rencana pembelajaran yang dirumuskan dalam Rencana Pelaksanaan Pembelajaran (RPP), di mulai dengan merumuskan tujuan pembelajaran yang akan di capai. Kemudian menentukan metode yang disesuaikan dengan materi pembelajaran dan tujuan pembelajaran. Merumuskan langkahlangkah kegiatan dalam pembelajaran, yang terdiri dari kegiatan awal, kegiatan inti dan kegiatan penutup. Kemudian mencantumkan dan mengembangkankan materi pembelajaran. Selanjutnya, menentukan media dan sumber belajar, serta merencanakan penilaian untuk mengetahui hasil belajar peserta didik.

Proses pembelajaran Pendidikan Jasmani Olahraga dan Kesehatan di SDN 11 Kota Bima dilakukan dengan tiga tahapan yaitu kegiatan awal, kegiatan inti, dan kegiatan penutup.

a. Kegiatan awal yang dilakukan oleh guru Pendidikan Jasmani Olahraga dan Kesehatan di SDN 11 Kota Bimadilakukan secara urut selalu di mulai dengan guru memberi salam dan berdoa bersama, selanjutnya menyapa peserta didik, selain itu pada beberapa pertemuan pembelajaran guru menanamkan kedisiplinan, guru menegur peserta didik yang tidak berpakaian lengkap. Pada beberapa pertemuan pembelajaran guru juga menanamkan nilai kebersihan dan kerapian, guru memeriksa kerapian dan kebersihan kuku. Selain itu, guru mengecek kehadiran peserta didik. Kemudian bertanya kepada peserta didik sampai dimana pembahasan sebelumnya dan mengajukan pertanyaan tentang materi pelajaran yang sudah diberikan sebelumnya, serta memberi kesempatan kepada peserta didik untuk bertanya tentang materi sebelumnya yang masih bingung dan menjelaskan kembali materi yang sebelumnya secara singkat.

b. Kegiatan inti, dalam kegiatan pembelajarannya guru selalu menyampaikan tujuan pembelajaran, menuliskan materi di papan tulis dan pada lain waktu menggunakan LCD Proyektor, menjelaskan materi dengan berpedoman buku paket dan modul kelas $\mathrm{V}$, melakukan tanya jawab terkait dengan materi dan peserta didik dapat menjawabnya dengan benar. Guru menggunakan lebih dari satu metode, antara lain yaitu menggunakan metode ceramah, tanya jawab, demonstrasi, praktek dan permainan. Selain itu, menggunakan media ketika pembelajaran, antara lain berupa papan tulis, LCD proyektor, net, peluit, bola. Setelah satu jam pembelajaran berlalu, pembelajaran di lanjutkan pindah di luar kelas, karena akan praktek olahraga. Pembelajaran di luar kelas di awali, dengan melakukan pemanasan, kemudian guru mendemonstrasikan gerakan sesuai dengan materi yang di ajarkan, kemudian peserta didik di minta untuk mempraktekan gerakan yang dicontohkan oleh guru secara bergantian, selain itu guru juga mengontrol gerakan yang dilakukan peserta didik, membetulkan gerakan yang salah. Setelah itu, 
guru memberikan kesimpulan tentang materi yang telah di ajarkan.

c. Kegiatan penutup yang dilakukan guru diantaranya adalah mengajukan pertanyaan kepada semua atau beberapa peserta didik mengenai materi yang telah dipelajari dan peserta didik dapat menjawabnya dengan benar, kemudian guru memberikan pekerjaan rumah kepada peserta didik untuk mengerjakan soal yang ambil dari buku paket Pendidikan Jasmani Olahraga dan Kesehatan dan LKS, kemudian memberitahukan materi pelajaran yang akan di pelajari pada pertemuan yang akan datang, selanjutnya pelajaran di tutup dengan doa dan guru mengucapkan salam

d. Evaluasi pembelajaran yang dilakukan oleh guru Pendidikan Jasmani Olahraga dan Kesehatan SDN 11 Kota Bimadengan melakukan penilaian terhadap tiga ranah, penilaian yang dilakukan guru Pendidikan Jasmani Olahraga dan Kesehatan agar dapat mengetahui hasil belajar peserta didik yaitu menyangkut kemampuan kognitif, afektif dan psikomotorik. Dalam penilaian ranah kognitif (pemahaman), di ukur dengan menggunakan tes tertulis dan dapat berupa tes lisan. Dalam penilaian ranah kognitif, guru menggunakan instrumen penilaian yang diambil dari buku paket Pendidikan Jasmani Olahraga dan Kesehatan dan LKS. Kemudian ranah afektif dilakukan guru selama berlangsungnya kegiatan belajar mengajar yaitu melalui pengamatan (observasi), guru mengamati aktif tidaknya siswa dalam pembelajaran Pendidikan Jasmani Olahraga dan Kesehatan, misalnya berani bersaing atau berkompetisi, bekerja sama dengan teman dan aktif bertanya dan merespon pertanyaan dari guru. Kemudian ranah psikomotorik dilakukan untuk mengukur praktek atau kinerja peserta didik, guru menggunakan tes unjuk kerja yang dilakukan setelah selesai satu pokok bahasan. Penilaian ini bisa menjadi nilai tambahan bagi siswa yang nilainya masih kurang dari KKM. Kemudian guru Pendidikan Jasmani Olahraga dan Kesehatan SDN 11 Kota Bima secara periodik melaksanakankan ulangan harian, ulangan tengah semester, dan ulangan semester.

\section{KESIMPULAN}

Dari data hasil penelitian dan pembahsan dapat disimpulkan bahwa pembelajaran pendidikan jasmani, olahraga dan kesehatan di SDN 11 Kota Bima sebagai berikut: 1)Pembelajaran yang di buat guru mata pelajaran Pendidikan Jasmani Olahraga dan Kesehatan di SDN 11 Kota Bimasecara prosedural sebelum proses pembelajaran guru merencanakan rencana pembelajaran yang dirumuskan dalam Rencana Pelaksanaan Pembelajaran (RPP),. 2)Proses pembelajaran Pendidikan Jasmani Olahraga dan Kesehatan di SDN 11 Kota Bima dilakukan dengan tiga tahapan yaitu kegiatan awal, kegiatan inti, dan kegiatan penutup., 3) Evaluasi pembelajaran yang dilakukan oleh guru Pendidikan Jasmani Olahraga dan Kesehatan SDN 11 Kota Bimadengan melakukan penilaian terhadap tiga ranah, penilaian yang dilakukan guru Pendidikan Jasmani Olahraga dan Kesehatan agar dapat mengetahui hasil belajar peserta didik yaitu menyangkut kemampuan kognitif, afektif dan psikomotorik

\section{Daftar Pustaka}

Sagala, Syaiful. Konsepdan Makna

Pembelajaran Untuk Memecahkan

Problematika Belajar dan Mengajar. Bandung: Alfabeta.

Samsudin. 2008. Pembelajaran Pendidikan Jasmani Olahraga dan Kesehatan SD/MI. Jakarta: Litera.

Sudjana, Nana. 2009. Dasar-Dasar Proses Belajar Mengajar. Bandung: Sinar Baru Algesindo.

Sudjiono, Anas. 2013. Pengantar Evaluasi Pendidikan. Jakarta: Raja Grafindo Persada.

Sugiyono. 2013. Metode Penelitian Pendidikan Kuantitatif, Kualitatif, $R \& D$. Bandung: Alfabeta.

Sukintaka. 2004. Teori Pendidikan Jasmani Filosofi Pembelajaran \& Masa Depan. Bandung: Nuansa.

Sunhaji. 2013. Pembelajaran Tematik-Integratif Pendidikan Agama Islam dengan Sains. Purwokerto: STAIN Press.

Sunhaji. 2012. Strategi Pembelajaran Konsep Dasar Metode dan Aplikasi dalam Proses Belajar Mengajar. Purwokerto: STAIN Purwokerto Press.

Suprayogo, Imam dan Tobroni. 2003. Metodologi Penelitian Sosial-Agama. 
Bandung: Rosdakarya.

Suryosubroto. 1997. Proses Belajar Mengajar di Madrasah. Jakarta: Rineka Cipta.

Suyono \& Hariyanto. 2012. Belajar dan Pembelajaran Teori dan Konsep dasar.

Bandung: PT. Remaja Rosdakarya.

UU RI NOMOR 20, SISDIKNAS \& Peraturan Pemerintah R.I.Tahun 2010 Tentang Penyelenggaraan Pendidikan Serta Wajib Belajar. Bandung: Citra Umbara.2011

Wina Sanjaya. 2008. Strategi Pembelajaran Berorientasi Standar Proses Pendidikan. Jakarta: Kencana.

Afrizal. 2016. "Di dalam tubuh yang kuat terdapat jiwa yang sehat", http://woibelilah.com/warta/kespora/168-wartakespora-woi-di-dalam-raga-yang- sehatterkandung-jiwa-yang-kuat,di akses pada 13 Juli 2016 pukul 13.00 . 